\title{
Maturation, fecundity and embryos development in three deep-water shrimps (Decapoda: Caridea: Pasiphaeidae, Oplophoridae) along the mid-Atlantic Ridge from Iceland to the Azores
}

\author{
Созревание, плодовитость и развитие эмбрионов у трех \\ глубоководных креветок (Decapoda: Caridea: Pasiphaeidae, \\ Oplophoridae) со Срединно-Атлантического хребта \\ от Исландии до Азорских островов
}

\author{
Svetlana A. Sudnik ${ }^{1}$, Tone Falkenhaug ${ }^{2}$ \\ С.А. Судник ${ }^{1}$, Т. Фалыкенхог ${ }^{2}$
}

\begin{abstract}
${ }^{1}$ Kaliningrad State Technical University, Sovietsky pr., 1, Kaliningrad, 236000 Russia. E-mail: lanasudnik@mail.ru Калининградский Государственный Технический Университет, Советский пр-т, Калининград, 236000 Россия. ${ }^{2}$ Institute of Marine Research, Flødevigen, N-4817, His, Norway. E-mail: tone.falkenhaug@imr.no
\end{abstract}

KEY WORDS: pelagic shrimps; reproductive strategies; sex identification; fecundity; embryos development. КЛЮЧЕВЫЕ СЛОВА: пелагические креветки, репродуктивные стратегии, определение пола, плодовитость, развитие эмбрионов.

ABSTRACT. The aim of this study is description of the reproductive characters of three species of deepwater caridean shrimps. Ovarian maturity staging and staging of embryos development in these species are described for the first time. Ovarian maturation, fecundity and eggs size, type of spawning and characteristics of embryos development integrally reflect reproductive patterns in Parapasiphae sulcatifrons, Acanthephyra pelagica and $A$. purpurea. All these species generally have K-strategy traits. However the two Acanthephyra spp. which live in shallower water layers and possess morphological plesiomorphies show K-strategy with important components of r-strategy (i.e. relatively large number of small but lecithotrophic larvae). $P$. sulcatifrons which is a bathypelagic species characterized by some apomorphies has extreme K-strategy traits and produces small numbers of large lecithotrophic larvae.

РЕЗЮМЕ. Цель данной работы - описание репродуктивных характеристик трех видов глубоководных каридных креветок. Стадии зрелости яичников и стадии развития эмбрионов у этих трех видов описываются впервые. Созревание яичников, величина плодовитости и размер яиц, тип нереста и развитие эмбрионов интегрально отражают специфику воспроизводства Parapasiphae sulcatifrons, Acanthephyra pelagica и A. purpurea. Всем видам присущи, главным образом, черты К-стратегии. Однако, оба вида Acanthephyra, более мелководных и имеющих ряд морфологических плезиоморфий, демонстрируют К-стратегию с тенденцией к r- стратегии (производят относительно большое количество лецитотрофных, но мелких личинок). Батипелагическая и характеризующаяся рядом апоморфий $P$. sulcatifrons имеет черты сильно выраженной К-стратегии с формированием небольшого количества крупных лецитотрофных личинок.

\section{Introduction}

Pelagic decapod shrimps often comprise a significant portion of biomass in midwater collections from the open ocean and play an appreciable role in the pelagic food web [Omori, 1974; Jamieson et al., 2009]. Despite a number of studies on the taxonomy and distribution of such pelagic shrimp species as Parapasiphae sulcatifrons Smith, 1884, Acanthephyra purpurea A. Milne-Edwards, 1881 and Acanthephyra pelagica Risso, 1816 [Vinogradov, 1968; Foxton, 1972; Crosnier, Forest, 1973; Hargreaves, 1984; Tchesunov, 1984; Kikuchi, Omori, 1985; Krygier, Wasmer, 1988; Hendrickx, Estrada Navarrete, 1989; Komai et al., 2000; Martin, 2003] there is still limited knowledge on their reproduction [Chace, 1940; Omori, 1974; Burukovsky, 1993, 1998; Burukovsky, Andreeva, 2011]. The aim of this paper is to describe traits of the reproductive system maturation (development of the primary and secondary sexual characters, maturation of ovaries), fecundity and embryos development in these deep-water species from the North Atlantic along the Mid-Atlantic Ridge from Iceland to the Azores and to discuss interspecific differences of their reproductive strategies. 
Table 1. Size of examined shrimp specimens.

Таблица 1. Размер исследованных особей креветок.

\begin{tabular}{|c|c|c|c|c|c|c|c|c|c|}
\hline \multirow[b]{2}{*}{ Species } & \multicolumn{3}{|c|}{ Juveniles } & \multicolumn{3}{|c|}{ Males } & & & \\
\hline & No. & $\begin{array}{r}\mathrm{TL}, \mathrm{mm} \\
\text { (in aver.) }\end{array}$ & $\begin{array}{l}\text { CL, mm } \\
\text { (in aver.) }\end{array}$ & No. & $\begin{array}{c}\text { TL, mm } \\
\text { (in aver.) }\end{array}$ & $\begin{array}{l}\mathrm{CL}, \mathrm{mm} \text { (in } \\
\text { aver.) }\end{array}$ & & & \\
\hline P. sulcatifrons & 43 & $\begin{array}{c}14.9-44.1 \\
(30.4)\end{array}$ & $\begin{array}{c}4.9-14.6 \\
(10.1)\end{array}$ & 305 & $\begin{array}{c}22.4 \\
74.9 \\
(54.6)\end{array}$ & $\begin{array}{c}7.4-24.8 \\
(18.0)\end{array}$ & & & \\
\hline A. pelagica & 106 & $\begin{array}{c}16.2-37.8 \\
(28.7)\end{array}$ & $\begin{array}{c}3.8-8.8 \\
(6.7)\end{array}$ & 568 & $\begin{array}{l}25.1- \\
124.9 \\
(70.1)\end{array}$ & $\begin{array}{c}5.9-29.3 \\
(16.4)\end{array}$ & & & \\
\hline A. purpurea & 5 & $\begin{array}{c}18.8-28.5 \\
(25.6)\end{array}$ & $\begin{array}{c}3.4-6.6 \\
(5.8)\end{array}$ & 89 & $\begin{array}{c}29.4 \\
90.3 \\
(59.3) \\
\end{array}$ & $\begin{array}{c}6.8-21.0 \\
(13.9)\end{array}$ & & & \\
\hline \multirow{3}{*}{ Species } & \multicolumn{9}{|c|}{ Females } \\
\hline & \multicolumn{3}{|c|}{ Total } & \multicolumn{3}{|c|}{ Non-oviparous } & \multicolumn{3}{|c|}{ Oviparous } \\
\hline & No. & $\begin{array}{r}\mathrm{TL}, \mathrm{mm} \\
\text { (in aver.) }\end{array}$ & $\begin{array}{l}\mathrm{CL}, \mathrm{mm} \\
\text { (in aver.) }\end{array}$ & No. & $\begin{array}{c}\mathrm{TL}, \mathrm{mm} \\
\text { (in aver.) }\end{array}$ & $\begin{array}{l}\mathrm{CL}, \mathrm{mm} \text { (in } \\
\text { aver.) }\end{array}$ & No. & $\begin{array}{l}\text { TL, mm (in } \\
\text { aver.) }\end{array}$ & $\begin{array}{l}\mathrm{CL}, \mathrm{mm} \text { (in } \\
\text { average }\end{array}$ \\
\hline P. sulcatifrons & 500 & $\begin{array}{c}20.6-98.9 \\
(60.3)\end{array}$ & $\begin{array}{c}6.8-32.7 \\
(19.7)\end{array}$ & 356 & $\begin{array}{c}20.6- \\
85.6 \\
(55.4)\end{array}$ & $\begin{array}{c}6.8-28.3 \\
(18.3)\end{array}$ & 144 & $\begin{array}{c}32.7-98.9 \\
(72.6)\end{array}$ & $\begin{array}{c}15.2-32.7 \\
(24.1)\end{array}$ \\
\hline A. pelagica & 664 & $\begin{array}{c}26.4- \\
106.1 \\
(68.9)\end{array}$ & $\begin{array}{c}6.2-24.8 \\
(16.1)\end{array}$ & 653 & $\begin{array}{l}26.4 \\
106.1 \\
(68.7) \\
\end{array}$ & $\begin{array}{c}6.2-24.8 \\
(16.1)\end{array}$ & 11 & $\begin{array}{c}68.6-98.0 \\
(80.9)\end{array}$ & $\begin{array}{c}16.07-22.9 \\
(18.9)\end{array}$ \\
\hline A. purpurea & 163 & $\begin{array}{c}30.5-91.4 \\
(58.3)\end{array}$ & $\begin{array}{c}7.2-21.2 \\
(13.6)\end{array}$ & 96 & $\begin{array}{c}30.5- \\
91.4 \\
(53.1)\end{array}$ & $\begin{array}{c}7.2-21.3 \\
(12.3)\end{array}$ & 67 & $\begin{array}{c}51.9-77.7 \\
(65.9)\end{array}$ & $\begin{array}{c}12.1-18.1 \\
(15.4)\end{array}$ \\
\hline
\end{tabular}

\section{Material and Methods}

Sampling was conducted during the Census of Marine Life (CoML) field project MAR-ECO (www.mareco.no) from 5 June to 3 July 2004 along the midAtlantic Ridge (MAR) area from Iceland $\left(\sim 60^{\circ} \mathrm{N}-\right.$ $\left.26^{\circ} \mathrm{W}\right)$ to the Azores $\left(\sim 41^{\circ} \mathrm{N}-28^{\circ} \mathrm{W}\right)$. The material was obtained using a pelagic "krill trawl" [see Wenneck et al. 2008 for details]. Hauls were performed in the depth range from 1.5 to $3008 \mathrm{~m}$. All samples were initially preserved in $4 \%$ borax neutralized formalin in seawater and later transferred to $75 \%$ ethanol for further storage. In order to study shrimp reproductive parameters in detail we use standard methodology for biological analysis [Burukovsky, 1992], that has been adopted for the pelagic shrimps [Sudnik, Falkenhaug, 2014]. These methods include: measuring of the total body length (TL) and of the carapace length (CL), sex identification, weighting of individual, ovary and egg clutches, identification of the ovary maturity stage (6stages, included both macroscopic and some microscopic features), identification of the stage of embryo development (5-stages), counting the absolute batch fecundity $(\mathrm{ABF}$, total amount of mature oocytes per prespawning female ovary) and the real [Burukovsky, 1994] batch fecundity (RBF), measuring of diameters of ripe oocytes and of eggs with embryos at the different development stages. To identify sex in Caridea the shape of the endopodite lobe of the first pleopod (which is regarded as a «copulatory appendage» (CA) for instance in pandalids) and the condition of appendix masculina (AM) on the endopodite of the second pleopod between appendix interna and the endopodite lobe were assessed [Allen, 1959; Burukovsky, 1992; Krol et al., 1992].

A total of 1338 specimens of A. pelagica (106 juveniles, 568 males, 664 females), 257 of $A$. purpurea (5 juveniles, 89 males, 163 females), and 874 of $P$. sulcatifrons (43 juveniles, 305 males, 500 females) were examined (Table 1). In twenty six specimens of $P$. sulcatifrons sex identification was not possible because of bad condition of their exoskeleton (Table 2). In 3 of 500 females of $P$. sulcatifrons and in 2 of the 828 of Acanthephyra spp. identification of ovarian maturity stages was not possible because of the bad condition of the material (Table 3). The absolute individual fecundity (AIF) is defined as the total number of ripe oocytes in the mature ovary (stage $\mathrm{V}$ ) produced by a female during the entire reproductive season. AIF could not be determined in this study because of the limited sampling period (one month). ABF was determined in $P$. sulcatifrons but it was not assessed in Acantephyra spp. because of too small and crumbled vitellogenic oocytes which could not be separated in the ethanol fixed ovary. In P. sulcatifrons (having large eggs) ripe oocytes sizes were measured in ovaries of 11 


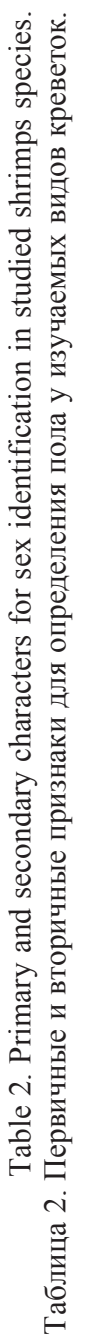

\begin{tabular}{|c|c|c|c|c|c|c|c|c|c|c|c|c|}
\hline \multirow{5}{*}{$\mid$} & 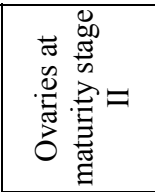 & 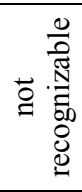 & 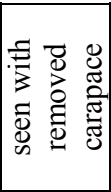 & \multicolumn{2}{|c|}{ 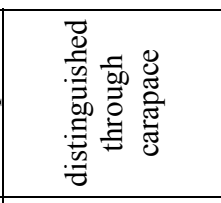 } & \multicolumn{2}{|c|}{ 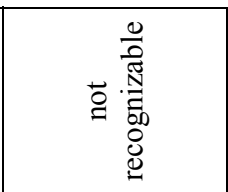 } & \multicolumn{2}{|c|}{ 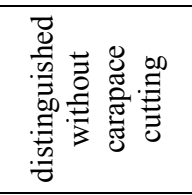 } & 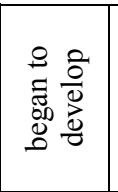 & 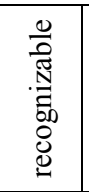 & 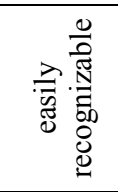 \\
\hline & 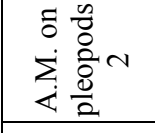 & $\begin{array}{l}\overrightarrow{0} \\
\text { ठै } \\
\text { ते }\end{array}$ & $\begin{array}{l}\text { 节 } \\
\text { ते }\end{array}$ & \multicolumn{2}{|c|}{$\begin{array}{l}\overrightarrow{\tilde{D}^{\circ}} \\
\text { 怘 }\end{array}$} & \multicolumn{4}{|c|}{$\begin{array}{l}\overrightarrow{\tilde{D}^{\prime}} \\
\text { त }\end{array}$} & \multicolumn{3}{|c|}{ 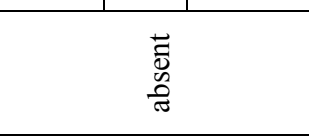 } \\
\hline & $\mathbb{U}$ & $\begin{array}{l}\overrightarrow{0} \\
0 \\
0 \\
\vdots\end{array}$ & $\begin{array}{l}\overrightarrow{\overline{0}} \\
\mathscr{D}_{\tilde{z}}\end{array}$ & \multicolumn{2}{|c|}{ 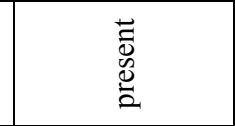 } & \multicolumn{4}{|c|}{$\begin{array}{l}\overrightarrow{\bar{v}} \\
\text { ते } \\
\vec{\sigma}\end{array}$} & \multicolumn{3}{|c|}{$\begin{array}{l}\text { च्च } \\
\text { ते } \\
\text { ते }\end{array}$} \\
\hline & 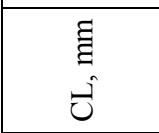 & $\begin{array}{l}0 \\
0 \\
0 \\
\stackrel{0}{0}\end{array}$ & $\frac{\pi}{d}$ & \multicolumn{2}{|c|}{ 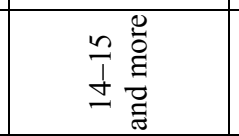 } & \multicolumn{2}{|l|}{$\frac{1}{b}$} & \multicolumn{2}{|c|}{ 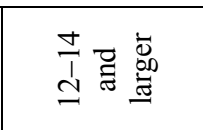 } & 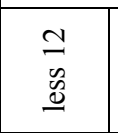 & $\stackrel{n}{\stackrel{1}{c}}$ & 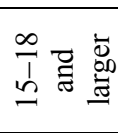 \\
\hline & 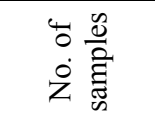 & $\stackrel{0}{0}$ & ஜ & \multicolumn{2}{|c|}{$\stackrel{\infty}{\vec{\gamma}}$} & \multicolumn{2}{|l|}{ 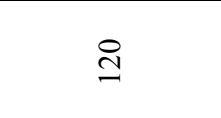 } & \multicolumn{2}{|c|}{ 导 } & $\mathscr{F}$ & ช్ & $\stackrel{\infty}{n}$ \\
\hline \multirow{6}{*}{$\frac{0}{\frac{0}{\pi}}$} & 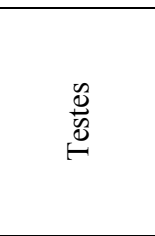 & 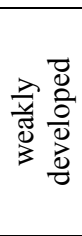 & 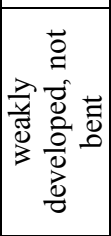 & 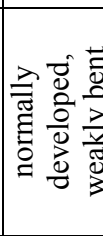 & 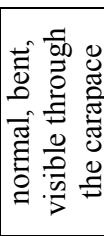 & 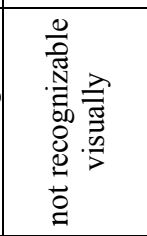 & 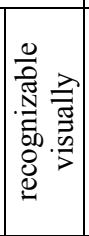 & 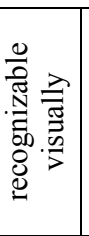 & 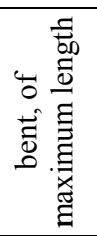 & 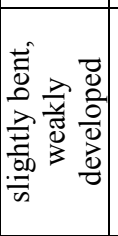 & 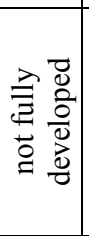 & 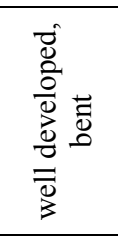 \\
\hline & \multirow{2}{*}{ 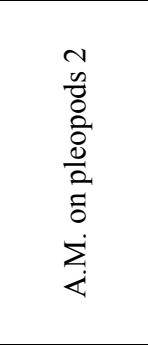 } & \multirow{2}{*}{$\begin{array}{l}\overrightarrow{0} \\
\text { हn } \\
\text { ते }\end{array}$} & \multirow{2}{*}{ 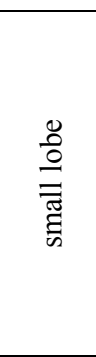 } & \multirow{2}{*}{ 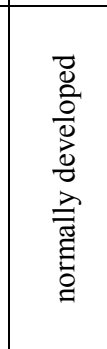 } & \multirow{2}{*}{ 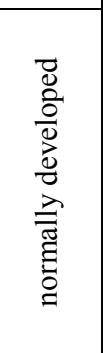 } & 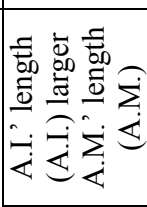 & 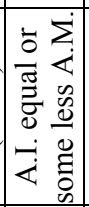 & $\begin{array}{l}\dot{\sum} \\
\dot{u} \\
\infty \\
0 \\
\dot{0} \\
\dot{z} \\
\dot{u}\end{array}$ & 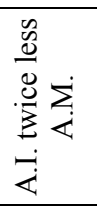 & 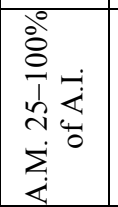 & 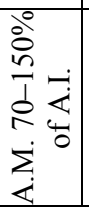 & 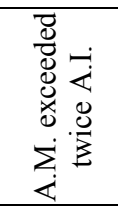 \\
\hline & & & & & & 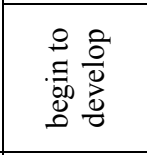 & 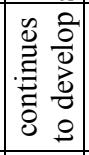 & 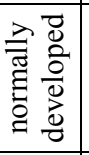 & 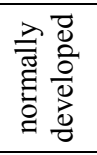 & 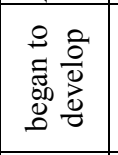 & 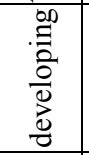 & 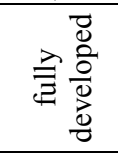 \\
\hline & 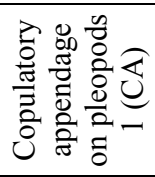 & 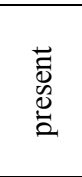 & 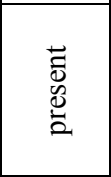 & $\begin{array}{l}\overrightarrow{0} \\
\overline{0} \\
0 \\
\text { ప. }\end{array}$ & 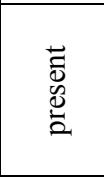 & 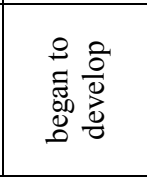 & 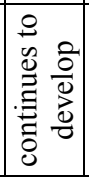 & 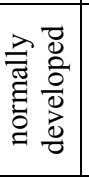 & 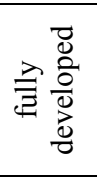 & 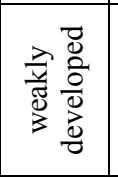 & 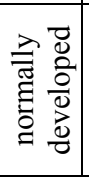 & 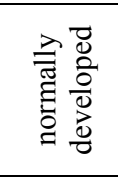 \\
\hline & ધે & $\frac{m}{1}$ & $\frac{n}{n}$ & $\frac{a}{1}$ & $\begin{array}{l}\tilde{a} \\
2\end{array}$ & $\begin{array}{l}\infty \\
b\end{array}$ & $\hat{a}$ & $\frac{a}{a}$ & 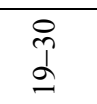 & 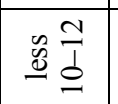 & $\begin{array}{l}M \\
\beth\end{array}$ & 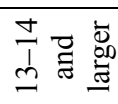 \\
\hline & 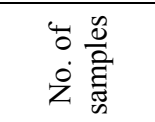 & $m$ & $\vec{m}$ & a & 年 & $\cong$ & $\nabla$ & 臬 & $\underline{I}$ & $\stackrel{i}{i}$ & $\circ$ & $\hat{n}$ \\
\hline \multirow{3}{*}{ 告 } & 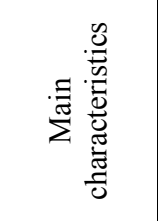 & \multicolumn{4}{|c|}{ 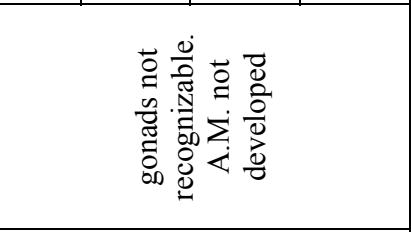 } & \multicolumn{4}{|c|}{ 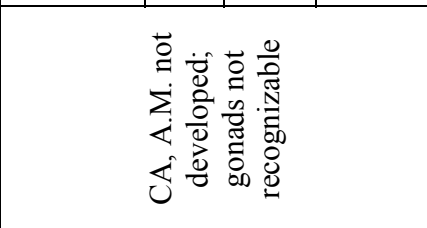 } & \multicolumn{3}{|c|}{ 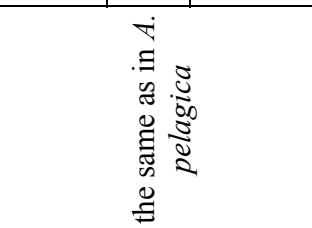 } \\
\hline & $\begin{array}{l}E \\
\tilde{z} \\
\hat{U}\end{array}$ & \multicolumn{4}{|c|}{ 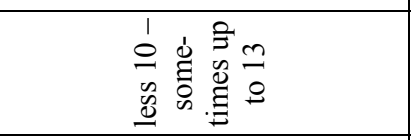 } & \multicolumn{4}{|c|}{ 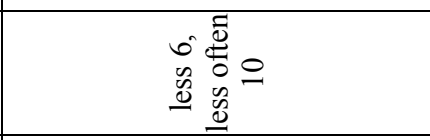 } & \multicolumn{3}{|c|}{ 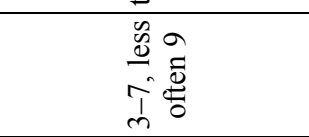 } \\
\hline & 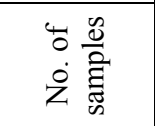 & \multicolumn{4}{|c|}{$q$} & \multicolumn{4}{|c|}{ 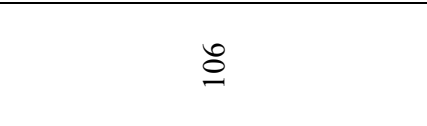 } & \multicolumn{3}{|c|}{ in } \\
\hline & 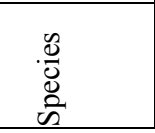 & \multicolumn{4}{|c|}{ 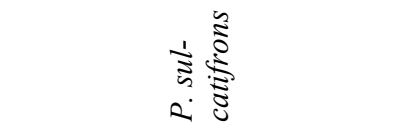 } & \multicolumn{4}{|c|}{$\frac{\pi}{8}$} & \multicolumn{3}{|c|}{ 离 } \\
\hline
\end{tabular}




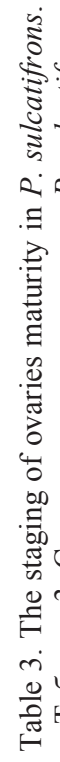

\begin{tabular}{|c|c|c|c|c|c|c|}
\hline 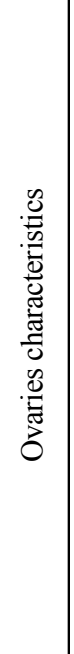 & & 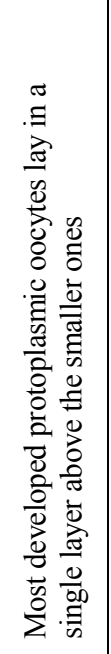 & 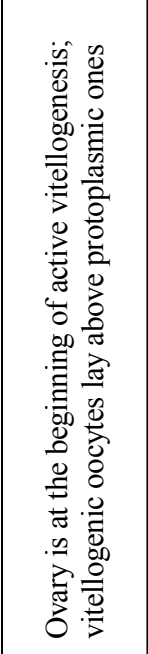 & 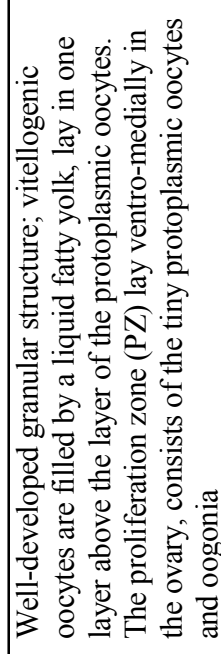 & 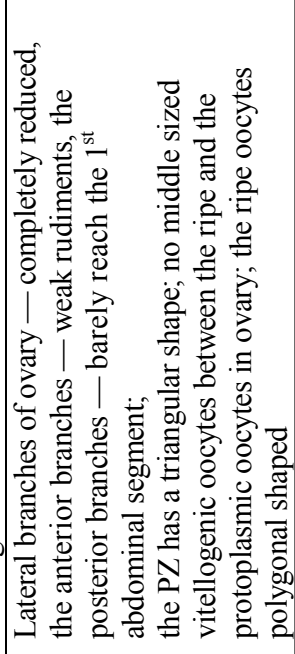 & 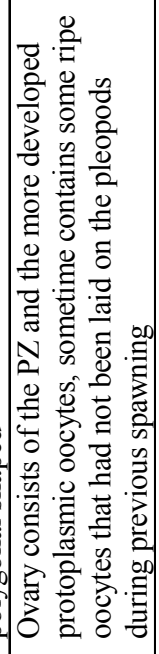 \\
\hline 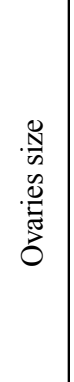 & 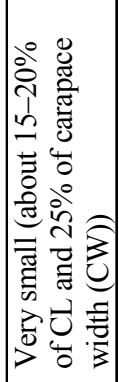 & 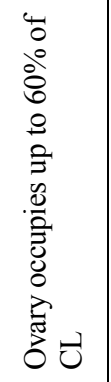 & 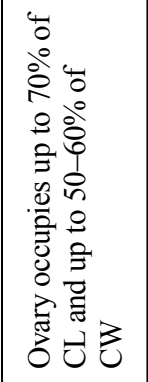 & 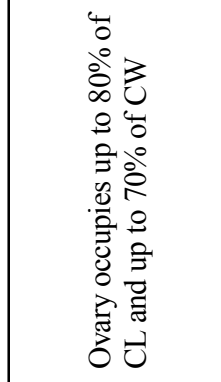 & 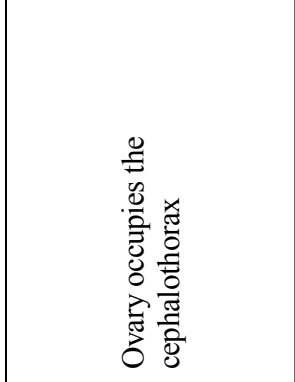 & 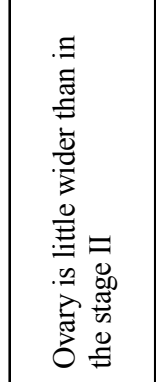 \\
\hline 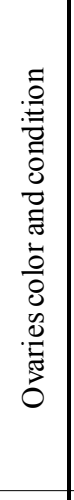 & 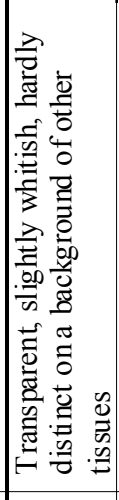 & 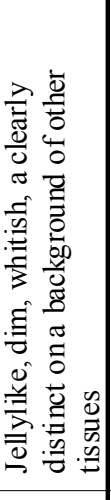 & 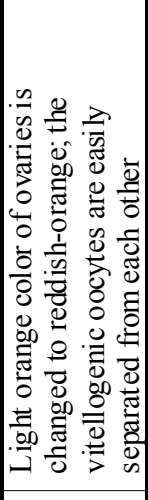 & 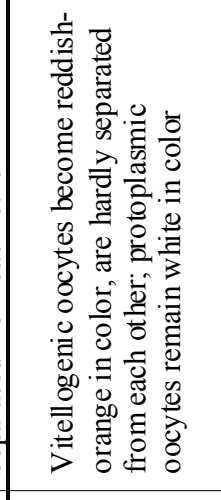 & 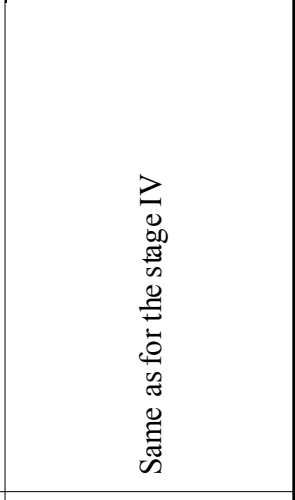 & 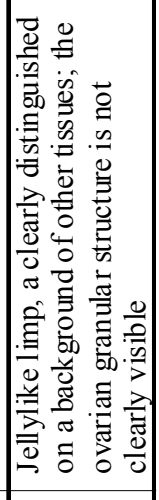 \\
\hline 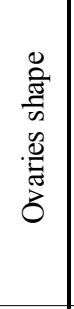 & 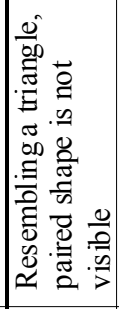 & 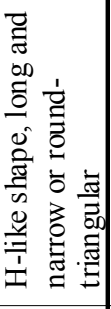 & 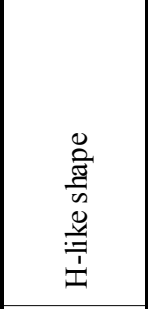 & 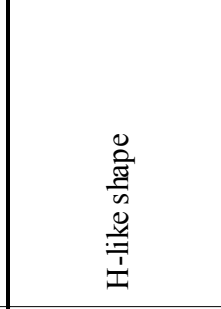 & 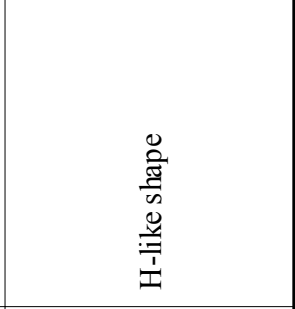 & 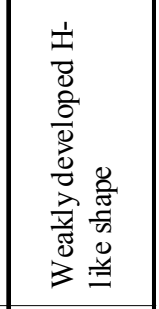 \\
\hline 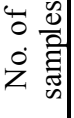 & + & ેㅏ & 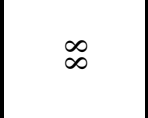 & $\hat{n}$ & in & - \\
\hline 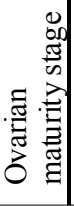 & - & $=$ & $\Xi$ & $z$ & $>$ & 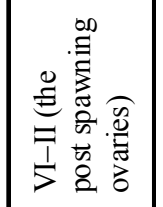 \\
\hline
\end{tabular}


females. The size of ripe oocytes was possible to measure in one prespawning female of $A$. pelagica. A total number of 203 females of three species were investigated for the identification of embryos development stages (144 of $P$. sulcatifrons, 11 of $A$. pelagica and 48 of $A$. purpurea). RBF defined as the number of eggs with embryos found on pleopods of an ovigerous female, was counted and eggs sizes were measured in 151 females of $P$. sulcatifrons, in 61 females of $A$. purpurea and in 21 specimens of $A$. pelagica. There were no $A$. pelagica females with newly laid eggs on pleopods in the material. Images of copulatory organs, eggs and sometimes gonads were made with the aid of a microsystem of Leica DFC420 camera. Images of shrimp body, gonads were made using a digital photo camera (Sony DSC-T10).

\section{Results}

\section{Parapasiphae sulcatifrons}

Total body length (TL) of the investigated specimens of $P$. sulcatifrons varied from $14.9 \mathrm{~mm}$ to 98.9 $\mathrm{mm}, 56.2 \mathrm{~mm}$ in average, the carapace length $(\mathrm{CL})$ from 4.9 to $32.7 \mathrm{~mm}, 18.6 \mathrm{~mm}$ in average (Table 1). Sex identification in $P$. sulcatifrons was possible using the shape of pleopod 2 but not the shape of pleopod 1 (its primary and secondary characters used for sex identification are presented in Table 2). The copulatory appendage (CA or copulatory organ) on pleopod 1 was observed both in males and in all females but appendix masculina (AM) on pleopod 2 was always absent in females (Fig. 1, 2). Specimens with CL less than $10 \mathrm{~mm}$ were regarded as juveniles (they had no visually distinguished primary and secondary sexual characteristics). In males the primary (testis and vas deferens) and the secondary (CA and AM) sexual characters began to develop nearly simultaneously (at CL 13-15 mm) and were fully developed yet at CL 19-21 $\mathrm{mm}$ (Fig. 7). Sizes of males and females (separately for non-oviparous and oviparous females) are presented in Table 1. The ratio of males to females was 1:1.6.

Description of ovarian maturity stages including the main macroscopic characters, including relative ovaries size, their condition, shape and color are presented in Table 3. Some microscopic features (the mutual disposition of oocytes of different developmental stages, indications of vitellogenesis in the ovary, oocytes size data) were added in the stage description for $P$. sulcatifrons (its large oocytes could be distinguished visually).

Shrimp females are ready for the first copulation at ovarian maturity stage II [Burukovsky, 1992]. Such females of $P$. sulcatifrons had CL 10-14 mm which could be defined as pubertal size. In females with $\mathrm{CL}$ larger $14-15 \mathrm{~mm}$ ovaries at maturity stage II could be identified without dissection of the carapace (Fig. 10, 11). Ovaries at this stage consisted of only protoplasmic oocytes that were clearly distinguished even without a microscope magnification and did not show visu- al indications of vitellogenesis. This previtellogenic condition was also confirmed by the histological study [Sudnik, 2008]. The ovaries increased considerably in length during stage III but they did not reach to the abdomen (Fig. 12). They had a light orange coloration owing to the beginning of active vitellogenesis. There were two types of oocytes in the ovary: one generation of vitellogenic oocytes (orange or reddish-orange in color, polygonal-shaped, approximately equal sized) was located dorsally and a thin layer of protoplasmic oocytes (much smaller and whitish in color) underlaid it ventrally. The vitellogenic oocytes have been increasing in size during stage IV owing to filling with liquid fatty yolk. Beneath the vitellogenic oocytes a band of protoplasmic oocytes with the proliferation zone was found ventro-medially in each ovary (Fig. 13, 14). The vitellogenic oocytes were about ten times larger than the most developed protoplasmic ones. No intermediate sized vitellogenic oocytes were found between the large sized vitellogenic and small sized protoplasmic oocytes in the ripe ovary (Fig. 15). Ripe oocytes lay in specific polygonal "cells" (Fig. 16). Postspawning ovaries (Fig. 17) often contained single large ripe orange oocytes that had not been laid on the pleopods during previous spawning. The average size of ripe oocytes in $P$. sulcatifrons ovaries was $3.44 \pm$ $0.28 \times 2.57 \pm 0.21 \mathrm{~mm}$ and the average ABF in $P$. sulcatifrons was $19 \pm 4$ ripe oocytes.

The main characteristics for five stages of embryos development and description of newly hatched larvae in $P$. sulcatifrons, the data on RBF values and eggs sizes are presented in Table 5 and illustrated in Figs $27,28,30,33,35$.

\section{A. purpurea and A. pelagica}

TL of the investigated specimens of $A$. purpurea ranged between 14.8 and $91.4 \mathrm{~mm}, 58.4 \mathrm{~mm}$ in average, CL: $3.4-21.3 \mathrm{~mm}, 13.5 \mathrm{~mm}$ in average; in $A$. pelagica TL was $16.2-124.9 \mathrm{~mm}, 66.2 \mathrm{~mm}$ in average, CL ranged from 3.8 to $29.3 \mathrm{~mm}, 15.5 \mathrm{~mm}$ in average (Table 1). Sex identification in Acanthephyra spp. was possible based both on the shape of CA of pleopod 1 and on the shape of AM on pleopod 2 (their primary and secondary traits for sex identification are presented in Table 2). Sizes of males and females (separately for non-oviparous and oviparous females) for both species are presented in Table 1. Sex ratio (males:females) was 1:1.8 in A. purpurea and 1:1.2 - in A. pelagica.

Specimens with CL of 6-9 $\mathrm{mm}$ and less in A. purpurea and those with CL less than $10 \mathrm{~mm}$ in A. pelagi$c a$ were identified as juveniles (Table 2).

In the males of $A$. pelagica secondary sexual characters began to develop some time earlier then the primary ones (testis) (Table 2). Males with CL 9-19 $\mathrm{mm}$ had well developed CA and AM (Fig. 3); their bended testes attained maximum length and were located along the entire dorsal side of cephalothorax, in particular covering the hepatopancreas (Figs. 8, 9). In the males of $A$. purpurea secondary and primary char- 

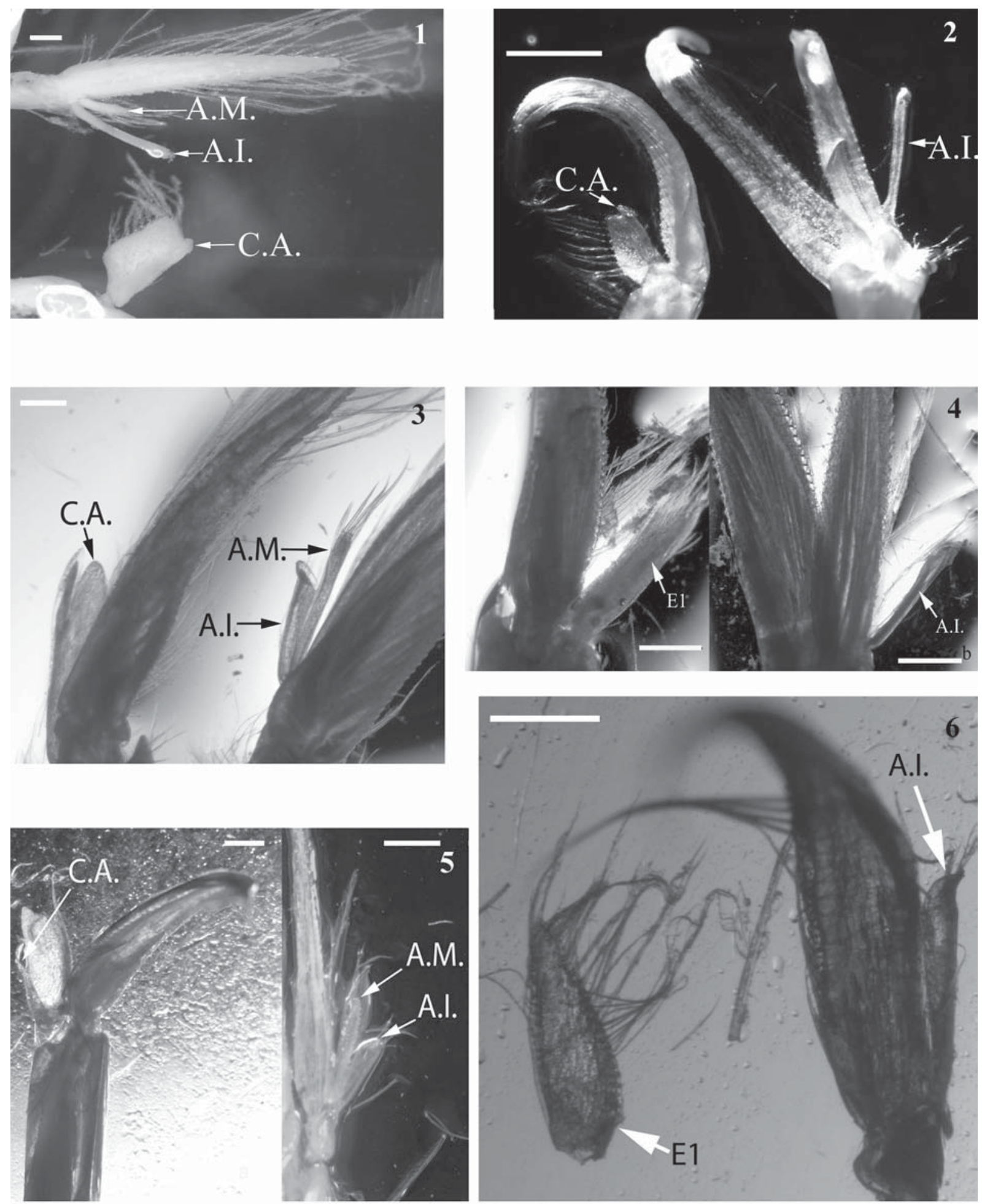

Fig. 1-6. Characters used for sex identification in Parapasiphae sulcatifrons, (1, 2), in Acanthephyra pelagica (3, 4), in A. purpurea $(5,6): 1,3,5$ - in males; 2, 4, 6 - in females. Abbreviations: E1 - endopodite of $1^{\text {st }}$ pleopods; C.A. — copulatory appendage on E1; A.I. a.interna on pleopod 2; A.M. - a.masculina on pleopod 2. Scale bars: 1-3, 5, 6-1 mm; $4-0.5 \mathrm{~mm}$.

Рис. 1-6. Признаки, использованные для определения пола у Parapasiphae sulcatifrons, (1, 2), у Acanthephyra pelagica (3, 4), у A. purpurea $(5,6): 1,3,5$ - у самцов; 2, 4, 6 - у самок. Сокращения: Е1 - эндоподит плеопод 1; С.А. — копуляторный вырост на E1; A.I. - a.interna на плеоподах 2; A.M. — a.masculina на плеоподах 2. Масштаб: 1-3, 5, 6-1 мм; 4 - 0,5 мм. 

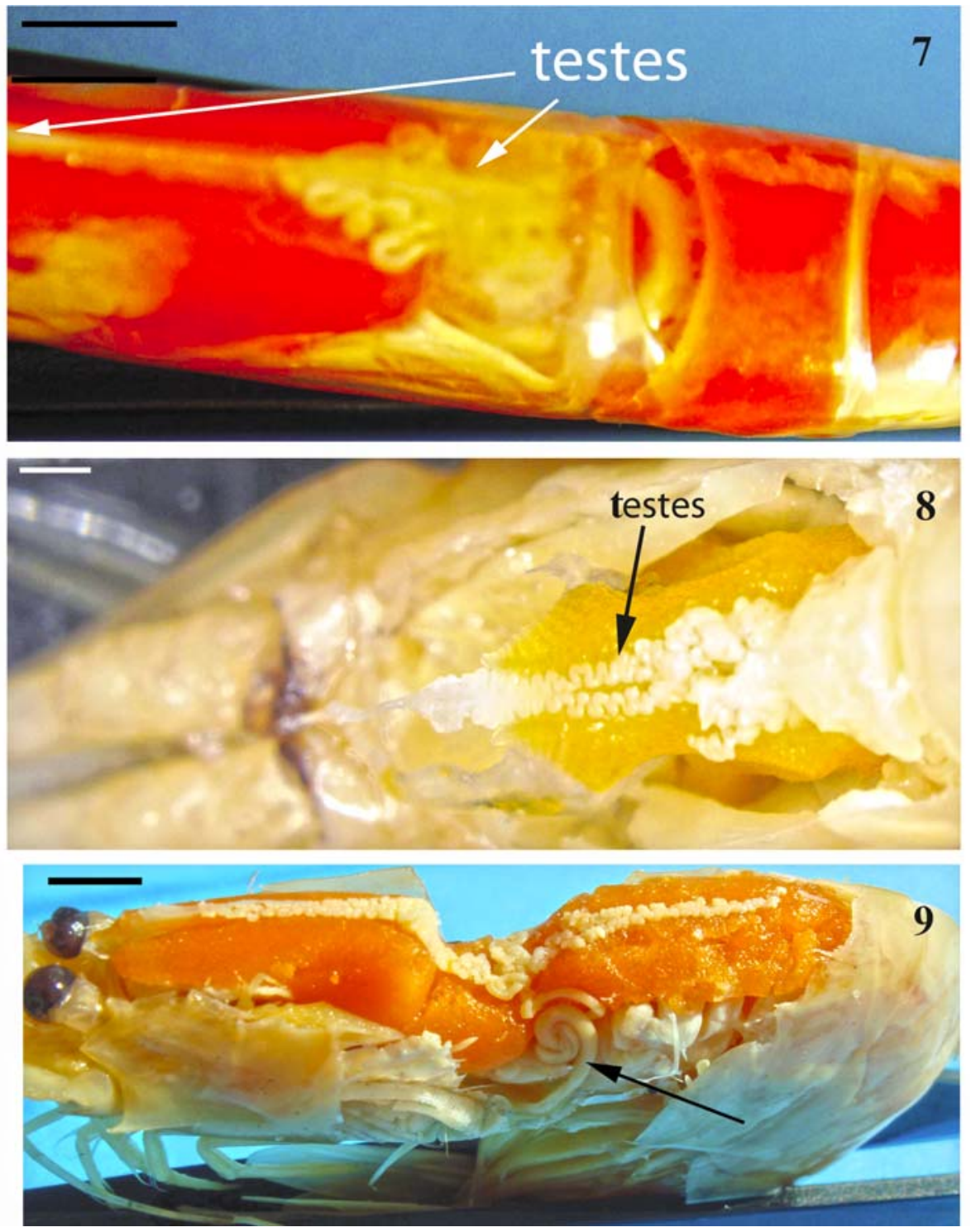

Fig. 7-9. Testes: 7 - of Parapasiphae sulcatifrons, dorsal view through the carapace; 8, 9- of A. pelagica: 8 - dorsal view; $9-$ lateral view, arrows show spiral vas differences. Scale bars: $\mathrm{a}-5 \mathrm{~mm} ; \mathrm{b}-10 \mathrm{~mm} ; \mathrm{c}-3 \mathrm{~mm}$.

Рис. 7-9. Семенники: 7 - Parapasiphae sulcatifrons, вид сверху через карапакс; 8, 9-A. pelagica: 8 - вид сверху; 9 - вид сбоку, стрелки показывают спиральные семяпроводы. Масштаб: a -5 мм; b -10 мм; с -3 мм.

acters showed nearly simultaneous development at CL 9-10 mm. Males with CL larger than 12-13 mm usually had CA and AM fully developed (Fig. 5) but their testes became fully developed and reached a characteristic bended shape only in males with CL 13-14 mm and larger. The testes are set along the entire dorsal side of the cephalothorax covering the hepatopancreas and reach to the end of $2^{\text {nd }}$ abdominal segment. Males larger than CL $16.5 \mathrm{~mm}$ had thicker and whiter testis, clearly visible through the carapace.

As a rule no CA on the endopodite lobe of pleopod 1 and no AM on pleopod 2 were found in females of Acanthephyra spp. (Figs 4, 6). In few cases of an abnormal development of female sexual characteristics a well-developed CA was found in A. pelagica females. However, this abnormality had not prevented these specimens to be functional females. A. purpurea and $A$. pelagica females were beginning to mature (ovaries on maturity stage II) at CL $12-14 \mathrm{~mm}$, but more frequently at CL $15-18 \mathrm{~mm}$. We identified six stages of ovarian maturity in Acanthephyra spp. The main macroscopic characters including relative ovaries size, their condition, shape and color are presented in Table 4. The ovaries became visible on the background of other tissues at early maturity stage II (Fig. 18, 19) At this stage ovaries extended in size in the lateral and the abdominal directions. At the stages III-IV they continue to increase considerably in their length and width (Figs 20-23). Ripe ovaries had a visible granular structure and were extended nearly over entire length of the carapace (Figs 24, 25). A characteristic size of ripe oocytes in A. pelagica ovaries was about $0.35 \times 0.09$ 

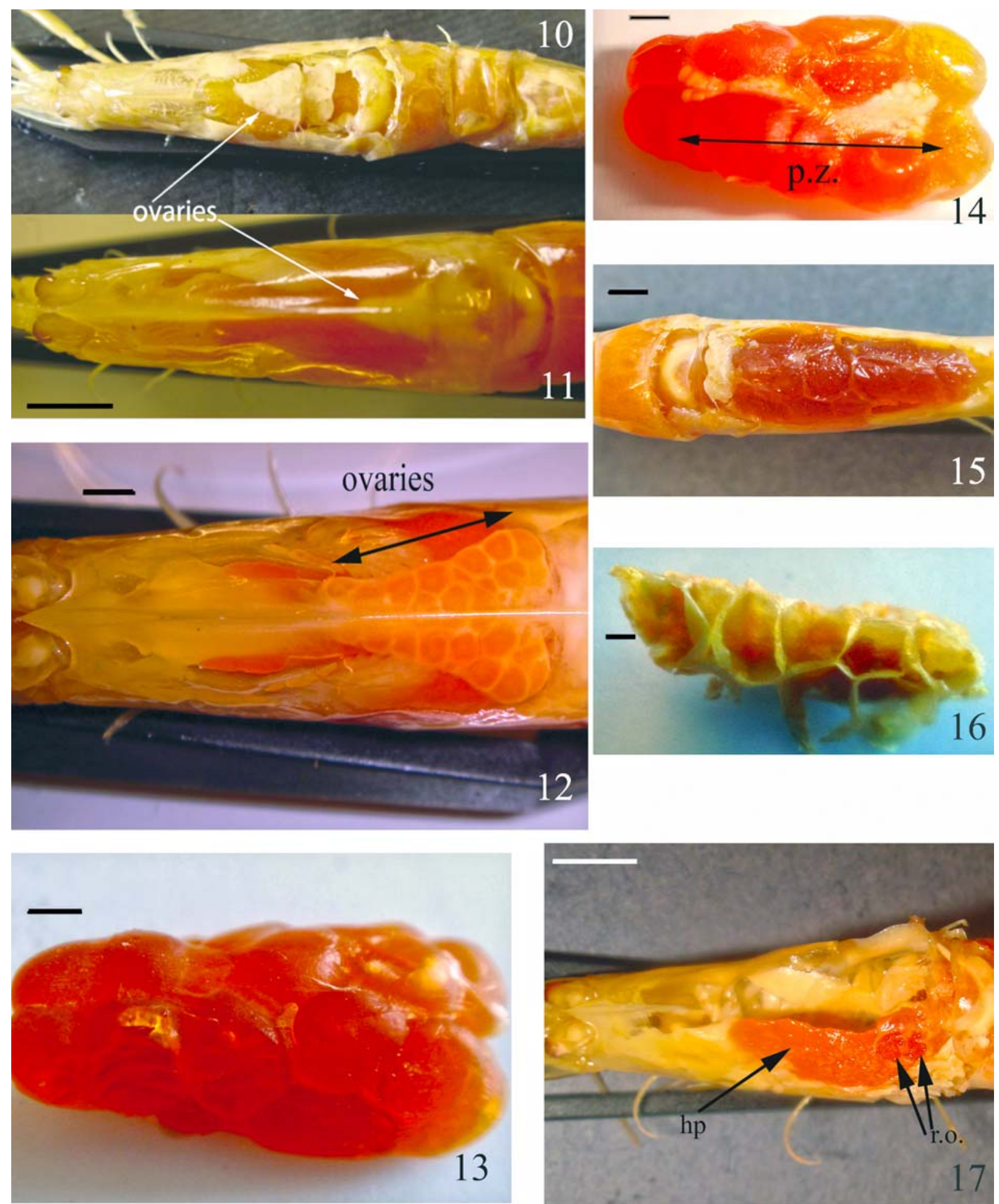

Fig. 10-17. Parapasiphae sulcatifrons, ovaries at different maturity stages: 10, 11 - stage II: 10 - without carapace; 11 - through the carapace; 12 - stage III; 13, 14 - stage IV; 15 - stage V; 16 - empty ovarian "cells" for ripe oocytes; 17 - stage VI-II (postspawning). 10-13, 15 - dorsal; 14 - ventral; 17 - lateral views. Abbreviations: p.z. - proliferation zone; hp - hepatopancreas; r.o. - ripe oocytes. Scale bars: $10,11,17-5 \mathrm{~mm} ; 12,13,14,15-2 \mathrm{~mm} ; 16-1 \mathrm{~mm}$.

Рис. 10-17. Яичники Parapasiphae sulcatifrons на разных стадиях зрелости: 10, 11 - стадия II: 10 - вид без карапакса; 11 вид сквозь карапакс; 12 - стадия III; 13, 14 - стадия IV; 15 - стадия V; 16 - пустые ячейки яичника для зрелых ооцитов; 17 стадия VI-II (посленерестовые самки). 10-13, 15 - дорсально; 14 - вентрально; 17 - латерально. Сокращения: p.z. - зона пролиферации; $\mathrm{hp}$ - гепатопанкреас; r.о. — зрелые ооциты. Масштаб: 10, 11, 17 - 5 мм; 12, 13, 14, $15-2$ мм; $16-1$ мм. 

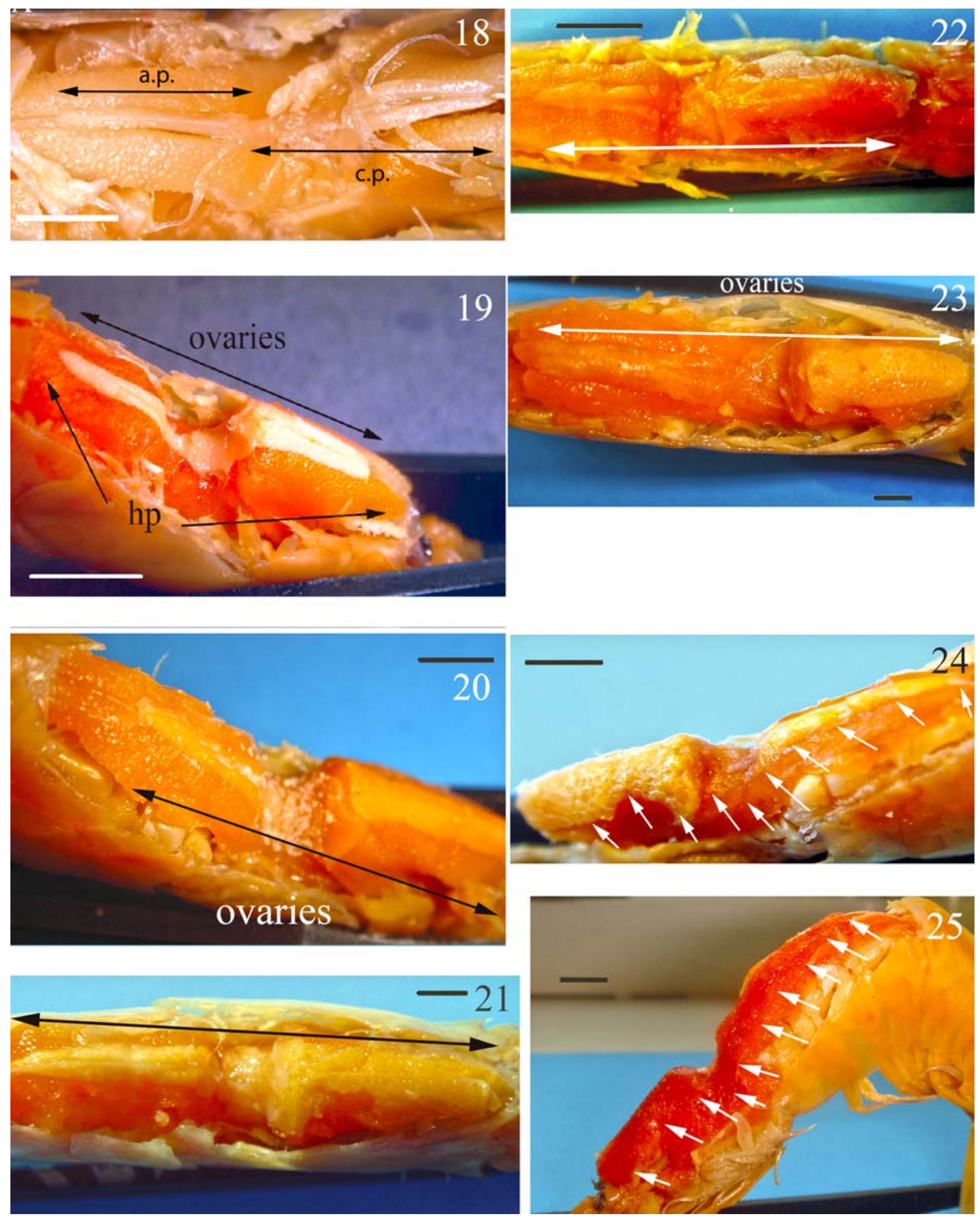

Fig. 18-25. Acanthephyra spp.' ovaries at different maturity stages: 18, 19 - stage II; 20, 21 - stage III; 22, 23 — stage IV; 24, 25 stage $\mathrm{V}$ (arrows show the ovaries location). 18, 20, 22, $24-$ A. purpurea; 19, 21, 23, 25 - A. pelagica. 18, 21, 22, 23 - dorsal; 19, $20-$ dorsolateral; 24, 25 - lateral views. Abbreviations: a.p. — abdominal part; c.p. — cephalothoracal part; hp — hepatopancreas. Scale bars: $18,24,25-5 \mathrm{~mm} ; 19-23-4 \mathrm{~mm}$.

Рис. 18-25. Яичники Acanthephyra spp. на разных стадиях зрелости: 1 - стадия II; 2 - стадия III; 3 - стадия IV; 4 - стадия V (стрелки показывают расположение яичников). 18, 20, 22, $24-$ A. purpurea; 19, 21, 23, 25 - A. pelagica. 18, 21, 22, 23 дорсально; 19, 20 - дорсолатерально; 24, 25 - латерально. Сокращения: а.р. — абдоминальная часть; с.р. — головогрудная часть; hp - гепатопанкреас. Масштаб: 18, 24, 25 - 5 мм; 19-23 - 4 мм. 
$\mathrm{mm}$. The main characteristics for five stages of embryos development and morphological observations on just hatched larvae in Acanthephyra spp., the data on RBF values and eggs sizes are presented in Table 5 and illustrated in Figs 26, 29, 31, 32, 34.

\section{Discussion}

The specimens of $A$. pelagica had a greater maximum total length (up to $125 \mathrm{~mm}$ ) then those of $A$. purpurea (up to $91.4 \mathrm{~mm}$ ) and of $P$. sulcatifrons (up to 98.9 $\mathrm{mm}$ ). The maximum sizes (TL) of females and males of A. pelagica $(7-15 \mathrm{~mm}$ in females and $35-50 \mathrm{~mm}$ in males) were also larger than in the two other species. Average sizes (TL) of females and males of P. sulcatifrons and of $A$. purpurea were similar being by $10-15$ $\mathrm{mm}$ less than the average TL of $A$. pelagica. The investigated area $\left(60-41^{\circ} \mathrm{N}, 26-28^{\circ} \mathrm{W}\right)$ is located somewhat north to the North Atlantic Subtropical Convergence (NASC) zone. In the NASC zone $\left(55-30^{\circ} \mathrm{N}, 2-35^{\circ} \mathrm{W}\right)$ [Burukovsky, Andreeva, 2010] external sexual characters of $A$. pelagica had developed fat larger size in both males and females, beginning from $55 \mathrm{~mm} \mathrm{TL}$ ) while the maximum male size (TL) was less (99 mm vs. $125 \mathrm{~mm}$ in our material). In $P$. sulcatifrons from the neighboring area $\left(46-37^{\circ} \mathrm{N}, 15-30^{\circ} \mathrm{W}\right)$ [Burukovsky, 1993] visual sex identification was possible in shrimps larger than 45 $\mathrm{mm}$ TL on, as compared to $21-22 \mathrm{~mm}$ in our material) and the maximum size (TL) of males and females was smaller than in our materials (up to 60 and 84 vs. 75 and $99 \mathrm{~mm}$, respectively). Development of sexual characters in $A$. purpurea from the same area $\left(46-37^{\circ} \mathrm{N}, 15-30^{\circ}\right.$ W) [Burukovsky, 1998] took place at larger size (TL), i.e. up to $57 \mathrm{~mm}$ vs. $29-31 \mathrm{~mm}$ in our specimens and the maximum sizes of both sexes were somewhat less than those from our material (up to $87 \mathrm{~mm}$ and 90-91.4 $\mathrm{mm}$ respectively). In a separate study we intend to discuss whether these differences are due to faster growth or longer ( $>3$ years) life span.

The study of functional maturation of an individual includes development of its reproductive system: gonads, copulatory and accessory organs, and secondary sexual characteristics, allowing the male to copulate and the female to be copulated and spawn. Difficulties with sex identification are common in the studies of shrimp biology, especially when dealing with sequential hermaphrodites changing their sex during the life history. Then it is necessary to examine gonads in addition to the condition of secondary (external) sexual characters.

In males of all investigated species ( $P$. sulcatifrons and Acanthephyra spp.) we observed simultaneous development of the primary and the secondary sexual characteristics. The morphology of pleopod 1 was not indicative for sex identification in P. sulcatifrons. This has also been documented in the crangonids Crangon crangon (Linnaeus, 1758) and Argis dentata (Rathbun, 1902) [Frechétte et al., 1970] and in the freshwater atyid shrimp Neocaridina denticulata (De Haan, 1844) [Oh et al., 2003]. However, in oplophorids of the genus
Acanthephyra, sex identification is possible by using the shape of both pleopods 1 and 2 as described for instance for Nematocarcinidae by Burukovsky [1992]. Oplophorid shrimps (Acanthephyra spp.) with their numerous morphological plesiomorphies in digestive, respiratory, reproductive systems, a structure of some exoskeleton elements [Martin, Davis, 2001; Burukovsky, 2003; Sudnik, 2008; De Grave, Fransen, 2011] are closer to nematocarcinids and may be considered as evolutionary old groups while the pasiphaeids with their morphological apomorphies in those systems are closer to crangonids, atyids and palaemonids, which are probably evolutionary advanced caridean groups.

The majority of carideans have H-like shaped ovaries, where two lateral parts are connected by a transverse part. Comparison of ovarian morphology using available literature indicated that ovaries of such mesoto upper bathypelagic species as $A$. pelagica, and $A$. purpurea are most similar to the ovaries of Nematocarcinidae, the epibenthic inhabitants of the continental slope. Nematocarcinus' ripe ovaries have the most primitive construction among carideans, showing some similarities to ovaries of penaeids: the anterior and the lateral branches ( 2 pairs) are rudimentary (typical for carideans), and the posterior branches reaches up to the end of abdomen (similar to peneids) [Burukovsky, 1992]. The species of Acanthephyra have a rather similar ovary morphology, where the posterior branches of ripe ovary reaches to the half of $3^{\text {rd }}$ abdominal segment (Table 4). In interzonal meso-bathypelagic Parapasiphae sulcatifrons as in other Pasiphaeidae such as Glyphus marsupialis Filhol, 1884 and Pasiphaea tarda Krøyer, 1845 [Sudnik, 2008] ovaries are very compact, including the central part, the anterior branches are rudimentary; their lateral branches are completely reduced and the posterior branches are possible to distinguish only in ripe condition, when they barely reach the $1^{\text {st }}$ abdominal segment (Table 3 ). The same was shown for Macrobrachium rosenbergii De Man, 1879 (Palaemonidae) [Jayachandran, 2001]. In the interzonal bathypelagic oplophorid shrimp, Systellaspis debilis A. Milne-Edwards, 1881 the ovary was compact, without any lateral and posterior branches and it barely reached to the $1^{\text {st }}$ abdominal segment [Sudnik, 2007]. Similar ovarian morphology was found in species of epibenthic pandalid shrimps (Plesionika ensis A. Milne Edwards, 1881, Plesionika edwardsii Brandt, 1851, Pandalus montagui Leach, 1814, Pandalus borealis Krøyer, 1838) [Mistakidis, 1957; Allen, 1959; Schultze, 1993; Sudnik, 2008] from the shelf and the upper part of continental slope: extremely weakly developed anterior branches were only met in the ripe ovary. In crangonid Argis dentata (Rathbun, 1902) [Frechétte et al., 1970] the ovaries are also very compact, and do not reach to the abdomen. Considering a general interpretation of shrimps evolutionary pathways [Burukovsky, 2003] we suppose the existence of evolutionary tendency to reduction the ovaries branches.

The ovarian structure in Acanthephyra spp. was difficult to study without histological investigation due 

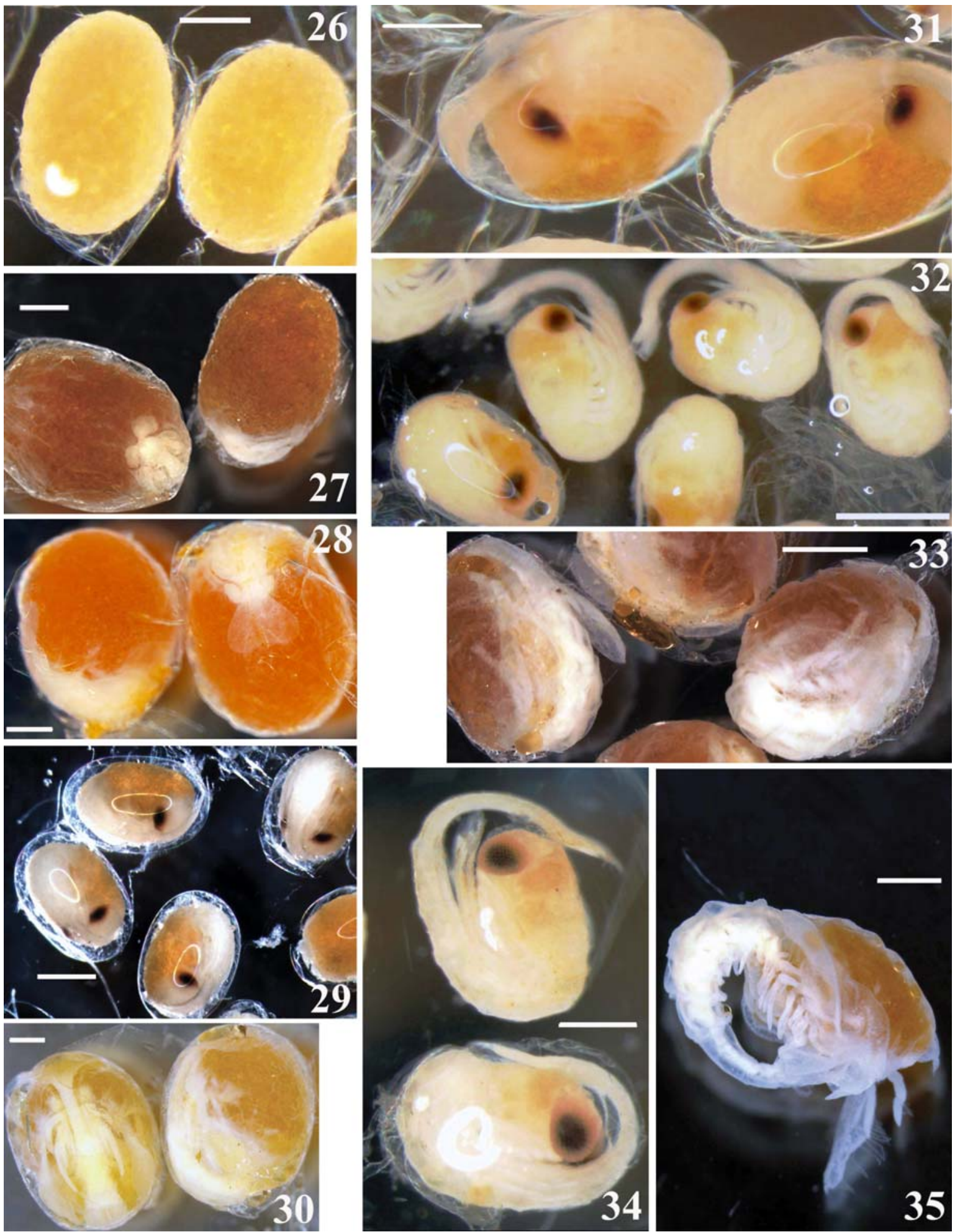

Fig. 26-35. The stages of embryos' development: 26 - stage $1 ; 27$ - stage $2 ; 28$ - stage $3 ; 29,30$ - stage 4; 31-33 - stage 5; 34, 35 - just hatched larvae; 26, 31 - Acanthephyra pelagica purpurea; 29, 32, $34-$ A. pelagica; 27, 28, 30, 33, 35 - Parapasiphae sulcatifrons. Scale bars: $26-0.25 \mathrm{~mm} ; 27,28-1 \mathrm{~mm} ; 29-0.5 \mathrm{~mm} ; 30,35-0.8 \mathrm{~mm} ; 31-0.3 \mathrm{~mm} ; 32-0.7 \mathrm{~mm} ; 33-1.5 \mathrm{~mm}$; $34-0.4 \mathrm{~mm}$.

Рис. 26-35. Стадии развития эмбрионов: 26 - стадия $1 ; 27$ - стадия 2; 28 - стадия $3 ; 29,30$ - стадия 4; 31-33 - стадия 5; 34,35 - только что вылупившиеся личинки; 26, 31 - Acanthephyra pelagica purpurea; 29, 32, 34 - A. pelagica; 27, 28, 30, 33, 35 - Parapasiphae sulcatifrons. Масштаб: 26 - 0,25 мм; 27, 28 - 1 мм; $29-0,5$ мм; 30, $35-0,8$ мм; $31-0,3$ мм; $32-0,7$ мм; $33-1,5$ мм; $34-0,4$ мм. 
Table 4. The staging of ovaries maturity in Acanthephyra spp.

Таблица 4. Стадии зрелости яичников Acanthephyra spp.

\begin{tabular}{|c|c|c|c|c|}
\hline $\begin{array}{l}\text { Ovaries } \\
\text { maturity stage }\end{array}$ & $\begin{array}{c}\text { No. of } \\
\text { samples }\end{array}$ & Ovaries shape & Ovaries condition & Ovaries characteristics \\
\hline I & 16 & $\begin{array}{l}\text { Very narrow; its } \\
\text { paired shape not } \\
\text { visible }\end{array}$ & $\begin{array}{l}\text { Transparent, hardly } \\
\text { distinct on a } \\
\text { background of other } \\
\text { tissues }\end{array}$ & $\begin{array}{l}\text { Ovary covers up to } 25 \% \text { of the distal part of } \\
\text { the stomach }\end{array}$ \\
\hline II & 440 & $\begin{array}{l}\text { Narrow in the } \\
\text { proximal } \\
\text { cephalothoracal and } \\
\text { in the abdominal } \\
\text { parts; enlarged in } \\
\text { the central } \\
\text { cephalothoracal part }\end{array}$ & $\begin{array}{l}\text { Jellylike, opaque, } \\
\text { visible distinguished on } \\
\text { a background of other } \\
\text { tissues }\end{array}$ & $\begin{array}{l}\text { In proximal part ovary occupies up to } 50- \\
70 \% \text { of } C L \text {, in central part - up to } 25-40 \% \\
\text { of CW; in distal part reaches to the } \\
\text { beginning of } 2^{\text {nd }} \text { abdominal segment; covers } \\
\text { up to } 50 \% \text { of distal part of the stomach }\end{array}$ \\
\hline III & 198 & $\begin{array}{l}\text { Same as for stage II; } \\
\text { H-like shape }\end{array}$ & $\begin{array}{l}\text { Weak granular } \\
\text { structure, light orange } \\
\text { in color }\end{array}$ & $\begin{array}{l}\text { Ovary occupies up to } 70-90 \% \text { of CL and up } \\
\text { to } 60 \% \text { of CW in its central part; its distal } \\
\text { part reaches to the half of } 2^{\text {nd }} \text { abdominal } \\
\text { segment; covers up to } 70 \% \text { of distal part of } \\
\text { the stomach }\end{array}$ \\
\hline IV & 104 & \multirow{2}{*}{$\begin{array}{l}\text { H-like shape, } \\
\text { narrower in its } \\
\text { abdominal part, a } \\
\text { narrow enough - in } \\
\text { the proximal } \\
\text { cephalothoracal part } \\
\text { and an enlarged in } \\
\text { the central } \\
\text { cephalothoracal part }\end{array}$} & $\begin{array}{l}\text { Clearly granular } \\
\text { structure, orange in } \\
\text { color }\end{array}$ & $\begin{array}{l}\text { Ovary occupies up to } 100 \% \text { of CL and up to } \\
80 \% \text { of CW; distal part reaches to the end of } \\
\text { the } 2^{\text {nd }} \text { abdominal segment }\end{array}$ \\
\hline V & 67 & & $\begin{array}{l}\text { Distinct granular } \\
\text { structure, orange in } \\
\text { color }\end{array}$ & $\begin{array}{l}\text { Ovary occupies cephalothorax and up to } \\
80 \% \text { of CW in its central part; its anterior } \\
\text { and lateral branches ( } 2 \text { pairs) are } \\
\text { rudimentary, the posterior branches of ripe } \\
\text { ovary extend up to the half of 3rd } \\
\text { abdominal segment. Distinguishing of ripe } \\
\text { vitellogenic oocytes is possible without } \\
\text { dissection of the carapace. }\end{array}$ \\
\hline $\begin{array}{l}\text { VI-II (the } \\
\text { post spawning } \\
\text { ovary) }\end{array}$ & 1 & $\begin{array}{l}\text { Ovary shape } \\
\text { narrower than it was } \\
\text { in stage II }\end{array}$ & $\begin{array}{l}\text { Jellylike, limp, } \\
\text { distinguished on a } \\
\text { background of the other } \\
\text { tissues; granular } \\
\text { structure not visible } \\
\end{array}$ & $\begin{array}{l}\text { The size of post spawning ovary varies in } \\
\text { the same limits as it is in the stage II; } \\
\text { differences are possible due to some not laid } \\
\text { large ripe oocytes }\end{array}$ \\
\hline
\end{tabular}

to their small oocyte sizes. In contrast to this, in ripe females of $P$. sulcatifrons the oocytes of previtellogenic and vitellogenic growth were clearly distinguished even without using a microscope. In their ovaries the proliferation zone lies ventro-medially, as it was shown for other shrimp species [Leloup, 1936; Mistakidis, 1957; Burukovsky, 1970; Relini, Semeria, 1983; Levi, Vacchi, 1988; Krol et al., 1992; Sudnik, 2008]. The maturity stages I and II correspond to immature ovaries in the period of protoplasmic growth of oocytes and possibly in the period of endogenous vitellogenesis [Sudnik, 2008, 2015; Burukovsky, Sudnik, 2014]. The period of active vitellogenesis (stages III-IV) is characterized by accumulation of exogenous yolk in most developed oocytes and changes of ovary color from whitish to orange. Our data showed that in P. sulcatifrons (similarly to another species with large oocytes, Oplophorus novaezelandiae (de Man, 1931) [Burukovsky, 1994]) the mature vitellogenic oocytes were filled with liquid fatty yolk. All vitellogenic oocytes in the ripe ovaries of $P$. sulcatifrons were mature, they were about 10 times larger than protoplasmic oocytes, and there were no middle sized vitellogenic oocytes in the ripe ovary of $P$. sulcatifrons. After spawning the ovaries returned to the immature condition (stage VIII). All this indicates a type of ovarian maturation where an asynchronic growth of oocytes without follicle (previtellogenic oocytes and oocytes with the indications of endogenous vitellogenesis) proceeds by a synchronic vitellogenesis of the most developed oocytes [terms by Burukovsky, Sudnik, 2014, Sudnik, 2015]. Similar situation was found in Farfantopenaeus notialis Burkenroad, 1939 [Burukovsky, 1970], Aristeus varidens Holthuis, 1952 [Burukovsky, Sudnik, 2004], in Nematocarcinus affricanus [Burukovsky, Sudnik, 2014], Systellaspis debilis, Glyphus marsupialis [Sudnik, 2007, 2015], in 11 species of penaeid and caridiean shrimps [Sudnik, 2008] on the basis of histological investigations of ovaries. This is expected in Acanthephyra spp., but needs to be confirmed through histological analyses of the ovary.

In most caridean shrimps and in some other decapods all ripe oocytes are described to be simultaneously laid on the pleopods [Heldt, 1938; Aoto, 1952; Burukovsky, 1970; Levi, Vacchi, 1988; Krol et al., 1992; Gorny, George, 1997; Kobayashi, 2003; RamirezLlodra, Segonzac, 2006; Sudnik, 2008, 2015]. This is in agreement with our results on $P$. sulcatifrons, $A$. 
Maturation, fecundity and embryos development in three deep-water shrimps

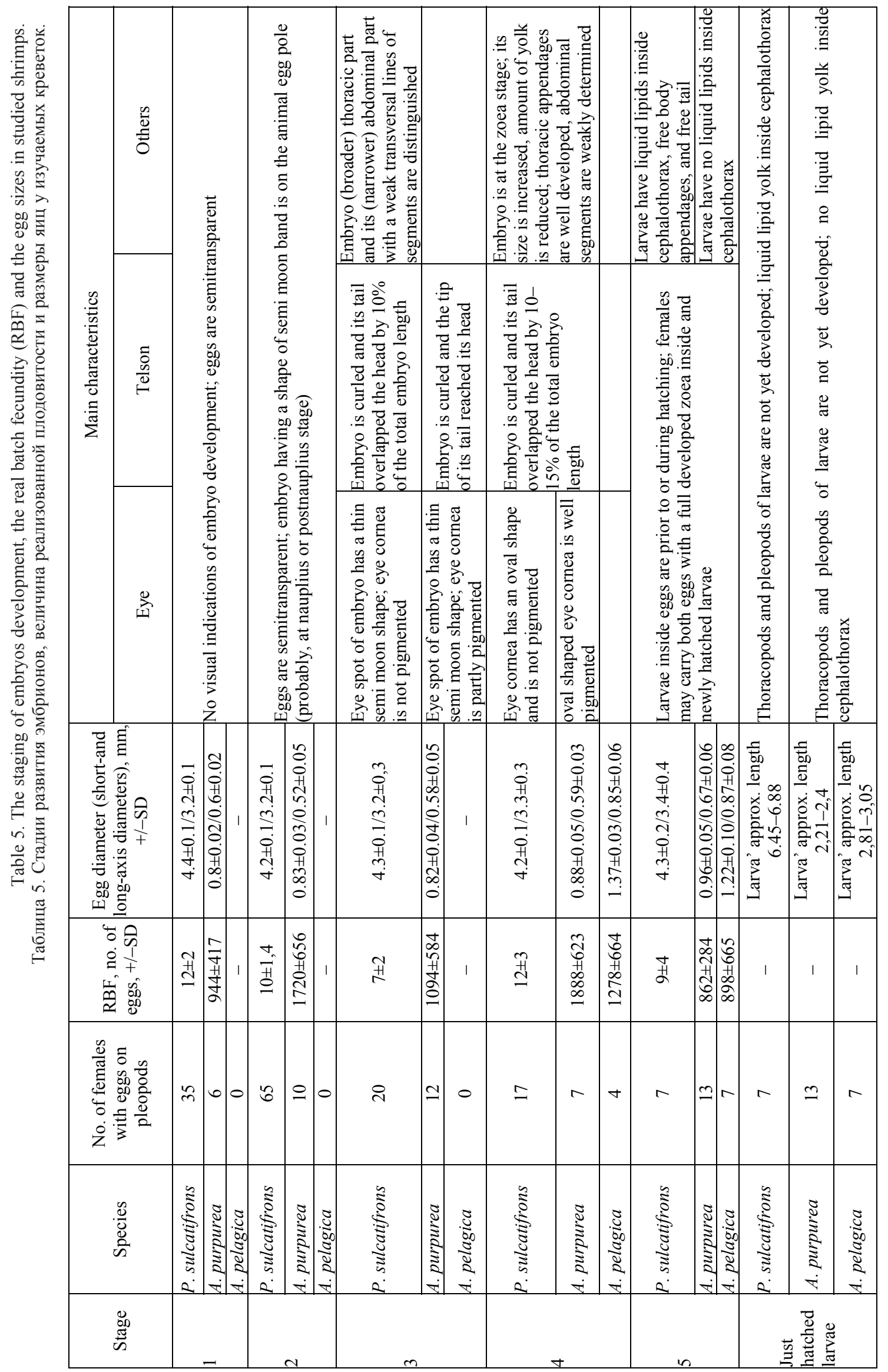


pelagica and A. purpurea where a synchronic vitellogenesis guarantees the onetime laying of all ripe oocytes during each spawning and we saw only equally developing oocytes on pleopods. Single portion of oocytes that have not been laid during a spawning event (see description of stages VI-II in Tab. 3, 4) have to be resorbed during the next gonadal cycle as it for many other decapod shrimp species [King, 1948; Aoto, 1952; Cummings, 1961; Burukovsky, 1970; Ville, 1972; Levi, Vacchi, 1988; Tan-Fermin, 1991; Demestre, Fortuno, 1992; Ramirez-Llodra, Segonzac, 2006; Sudnik, 2008] and for other animals [Eisenstadt, 1977; Ivankov, 1985; Kasyanov, 1989; Nigmatullin, 2000].

The RBF and egg sizes on each embryos development stage differed by orders of magnitude between $P$. sulcatifrons and Acanthephyra spp. The interzonal bathypelagic species $P$. sulcatifrons (600-2100 $\mathrm{m}$ and deeper) had a rather compact ovary and its fecundity (RBF) was less than 20 eggs per female in average. On the contrary, the interzonal mesopelagic-upper bathypelagic species Acanthephyra spp. (100-200 to 1800 $2000 \mathrm{~m}$ ), had well-developed distal branches in the ripe ovary and their RSF attained more than 2000 eggs per female in average (Tab. 5). In addition, considerable differences in eggs sizes were noted. The sizes of newly laid eggs in pasiphaeid shrimps $P$. sulcatifrons $(4.4 \pm 0.1 \times 3.2 \pm 0.1 \mathrm{~mm}$; Tab. 5) and Glyphus marsupialis $(4.8-6.5 \times 3.9-5.1 \mathrm{~mm})$ [Sudnik, 2007], as in oplophorids Oplophorus novaezilandie (2.6-2.8 × 1.6$2.7 \mathrm{~mm}$ ) [Burukovsky, 1994] and Systellaspis debilis (3.4-3.6 × 1.97-2.2 mm) [Sudnik, 2015] were much larger than in the oplophorid A. purpurea $(0.8 \pm 0.02 \times$ $0.6 \pm 0.02 \mathrm{~mm}$ : Tab. 5). The sizes of the newly hatched larvae in $P$. sulcatifrons were more than twice as large as larvae of Acanthephyra spp. (approximately 6.5-7 $\mathrm{mm}$ and not more than $3.2 \mathrm{~mm}$, respectively: Tab. 5) and had storage of liquid lipids inside the cephalothorax. A more compact shape of the ovary coincides with a decrease in fecundity and increase in the egg size, which is found in caridean shrimps that have adapted to a mode of bathypelagic life.

Both Acanthephyra spp. and Parapasiphae sulcatifrons demonstrate the K-strategy traits typical for all carideans (a well-developed care of offspring), i.e. the shrimps carry their eggs on the pleopods and evolve in the direction to develop larger eggs and larger lecithotrophic larvae, compared to penaeids. The aristeids and penaeids show indications of r-strategy and release their numerous small eggs in the water, where mainly planctotrophic larvae develop. Acanthephyra spp. have more numerous and smaller eggs and smaller lecithotrophic larvae compared to pasiphaeids, other oplophorids and other caridean species [this study; Sudnik, 2008, 2015]. Acanthephyra spp. show indications of both K-strategy (incubations of embryos on pleopods) and the tendency to r-strategy (numerous small embryos and newly hatched larvae), which was classified as K-r-strategy according to Sudnik [2008]. A. pelagica and $A$. purpurea have a more shallow distribution range than $P$. sulcatifrons and are probably morphologically closer to the older evolutionary shrimp groups (nematocarcinids, penaeids: [Burukovsky, 2003]). P. sulcatifrons has few large eggs and large lecithotrophic larvae which can be regarded as components of KK-strategy (extreme K-strategy: [Sudnik, 2008]). P. sulcatifrons is a bathypelagic species and, according to Burukovsky [2003] and our results, it morphologically corresponds to evolutionary younger shrimp groups. The decrease in fecundity in species adapted to the deepwater life is related to the reproductive strategy which is directed towards formation of large well developed lecithotrophic larvae. Both large and advanced larvae with the storage of liquid lipids inside the cephalothorax are considered to increase the chances of survival at low temperatures and limited food availability in the bathypelagic waters.

ACKNOWLEDGEMENTS. This study was an element of MAR-ECO (2001-2010), an international field project under the Census of Marine Life. We thank the crew and scientists on the R/V GO Sars for help during collecting and sorting of crustacean catches. We are indebted to Hege Øverbø Hansen (IMR, Norway) for her help during species identification. V. Laptikhovsky (the Falklands, UK), R.N. Burukovsky (KSTU, Kaliningrad, Russia) for the help in locating relevant literature. We wish to thank all colleagues and especially Ch.M.Nigmatullin (AtlantNIRO, Kaliningrad), V.A. Spiridonov (IO RAS, Moscow) who provided helpful advices and critical reading of the manuscript.

\section{References}

Allen J.A. 1959. On the biology of Pandalus borealis Kroyer, with reference to a population off the Northumberland coast // Journal of the Marine Biological Association of the United Kingdom. Vol.38. P.189-220.

Aoto T. 1952. Sexual phases in the prawn, Pandalus kessleri Czerniavski, with special reference to reversal of sex // Jour. Fac. Sci. Hokkaido Univ. Ser VI. Zoology. Vol.11. No.1. P.1-20.

Burukovsky R.N. 1970. [Some aspects of pink shrimp (Penaeus duorarum) oogenesis] // Archiv anatomii, histologii i embryologii. T.58. No.6. P.56-66 [in Russian].

Burukovsky R.N. 1992. [Method of the biological analysis of some tropical and subtropical shrimps] // Ivanov B.G. (ed.). Promyslovo-biologicheskie issledovaniya morskih bespozvonochnyh. Moscow. P.77-84 [in Russian].

Burukovsky R.N. 1993. [Biology of shrimp Parapasiphaea sulcatifrons] // Biologiya morya. No.3. P.45-52 [in Russian]

Burukovsky R.N. 1994. On the biology of shrimp Oplophorus novaezealandiae De Man, 1931, from Namibian waters (Crustacea, Decapoda, Oplophoridae) // Arthropoda Selecta. Vol.3. Nos.1-2. P.3-12.

Burukovsky R.N. 1998. [Biology of shrimp Acanthephyra purpurea Milne-Edwards, 1881 (Crustacea, Decapoda, Oplophoridae)] // Byull. Mosk. obshchestva ispytateley prirody. Otd. Biol. T.103. Vyp.6. P.17-25 [in Russian].

Burukovsky R.N. 2003. [On the process of shrimps evolution (Crustacea, Decapoda, Natantia)] // Burukovsky R.N., Tsarevsky Ju.P. (eds). Problemy gidrobiologii i ikhtiopatologii. Kaliningrad: KGTU. P.44-52 [in Russian]

Burukovsky R.N., Andreeva V.M. 2010. [On the geographic distribution, bathymetry and biology of Acanthephyra pelagica (Risso 1816) (Decapoda, Oplophoridae) // Journal of Siberian Federal University. Ser. Biologiya. T.3. No.3. P.303-321 [in Russian].

Burukovsky R.N., Sudnik S.A. 2004. [Some aspects of oogenesis of shrimp Aristeus varidens Holthuis 1952 (Decapoda, 
Aristeidae)] // Zoologicheskiy zhurnal. T.83. No.3. P.288-298 [in Russian, with English summary].

Burukovsky R.N., Sudnik S.A. 2014. [Oogenesis and ovaries maturation as a basis of reproductive strategy in shrimp females Nematocarcinus africanus Crosnier et Forest 1973 (Crustacea, Caridea, Nematocarcinidae)] // Nauka i mir. Vol.2. No.12(16). P.16-24 [in Russian].

Chace F.A.Jr. 1940. The bathypelagic Caridean Crustacea. Plankton of the Bermuda Oceanographic Expedition IX // Zoologica. Vol.25. P.140-144.

Crosnier A., Forest J. 1973. Less crevettes profondes de l'Atlantique oriental tropical // Faune Tropicale (O.R.S.T.O.M). Vol.19. P.1-409.

Cummings W.C. 1961. Maturation and spawning of the pink shrimp, Penaeus duorarum Burkenroad // Transactions of the American Fisheries Society. Vol.90. No.4. P.462-468.

De Grave S., Fransen C.H.J.M. 2011. Carideorum catalogus: the recent species of the dendrobranchiate, stenopodidean, procarididean and caridean shrimps (Crustacea: Decapoda) // Zoologische Mededelingen. Vol.85. No.9. P.195-588.

Demestre M., Fortuno J.M. 1992. Reproduction of the deep-water shrimp Aristeus antennatus (Decapoda: Dendrobranchiata) // Marine Ecology Progress Series. Vol.84. P.41-51.

Foxton P. 1972. Observations on the vertical distribution of the genus Acanthephyra (Crustacea, Decapoda) in the eastern North Atlantic, with particular reference to the "purpurea" group // Rutherford W.H. (ed.). Proceedings of the Royal Society of Edinburgh. Section B. Biology. Vol.73. P.301-313.

Frechétte J., Corrivault G.W., Couture R. 1970. Hermaphrodisme protérandrique chez une crevette de la famille des Crangonidés Argis dentata // Naturaliste canadien. Vol.39. P.805-822.

Gorny M., George M.R. 1997. Oocyte development and gonad production of Nematocarcinus lanceopes (Decapoda: Caridea) in the eastern Weddell Sea, Antarctica // Polar biology. Vol.17. P.191-198.

Hargreaves P.M. 1984. The distribution of Decapoda (Crustacea) in the open ocean and near-bottom over an adjacent slope in the northern Northeast Atlantic Ocean during autumn 1979// J. Mar. Biol. Ass. U.K. Vol.64. P.829-857.

Heldt J.H. 1938. La reproduction chez les Crustacés Décapodes de la famille des Penaeids // Annales de l'Institut océanographique. Vol.18. No.2. P.31-206.

Hendrickx M.E., Estrada Navarrete M.D. 1989. A checklist of the species of pelagic shrimps (Penaeoidea and Caridea) from the Eastern Pacific, with notes on their geographic and depth distribution // California Cooperative Oceanic Fisheries Investigations (CalCOFI) Reports. Vol.30. P.104-121.

Ivankov V.N. 1985. [Fish fecundity. Methods of its determination, its variability, laws of its formation]. Vladivostok: Dalnevostochnyi Universitet Publ. 88 p. [In Russian].

Izenshtadt T.B. 1977. [Modern problems of oogenesis] Moscow: Nauka. 314 p. [In Russian].

Jamieson A.J., Fujii T., Solan M., Matsumoto A.K., Bagley P.M., Priede I.G. 2009. First findings of decapod Crustacea in the hadal zone // Deep-Sea Research. Vol.1. No.56. P.641-647.

Jayachandran K.V. 2001. // Palaemonid prawns. Biodiversity, taxonomy, biology and management. Enfield: Science Publishers. P.420-436.

Kasyanov V.L. 1989. [Reproductive strategy of marine bivalve mollusks and echinoderms]. Leningrad: Nauka. 179 p. [In Russian].

Kikuchi T., Omori M. 1985. Vertical distribution and migration of oceanic shrimps at two locations off the Pacific coast of Japan // Deep-Sea Research. Vol.32. No.7. P.837-851.

King J.E. 1948. A study of the reproductive organs of the common marine shrimp, Penaeus setiferus (Linnaeus) // Biological Bulletin. Vol.94. P.244-262.

Kobayashi S. 2003. Process of maturity and reproduction of female Japanese mitten crab Eriocheir japonica (De Haan) // Crustacean research. Vol.32. P.32-44.

Komai T., Kikuchi T., Nakaguchi K., Go A. 2000. Pelagic shrimps (Crustacea: Decapoda: Penaeidea and Caridea) from the Ohsumi Islands and southern Kyushu, Japan, collected by TRV
"Toyoshio-maru" during cruises in 1996-1998 // Journal of the Faculty of Applied Biological Science. Vol.38. P.131-149.

Krol R.M., Hawkins W.E., Overstreet R.M. 1992. Reproductive components // Microscopic Anatomy of Invertebrates. Vol.10. Decapod Crustacea, Chapt.8. N.Y.: Wiley-Liss Inc. P.295-343.

Krygier E.E., Wasmer R.A. 1988. Zoogeography of pelagic shrimps (Natantia: Penaeidea and Caridea) in the North Pacific Ocean (with synopses and keys to the species of the Subarctic and Transitional Zones) // Bulletin of the Ocean Research Institute. Vol.26. No.1. P.43-98.

Leloup E. 1936. Les transformations des gonades et des caractères sexuels externes chez Pandalus montagui Leach (Décapode) // Bulletin du Musée Royal d'Histoire Naturelle de Belgique. Vol.12. No.19. P.1-27.

Levi D., Vacchi M. 1988. Macroscopic scale for simple and rapid determination of sexual maturity in Aristemorpha foliacea (Risso, 1826) (Decapoda: Penaeidae) // Journal of Crustacean Biology. Vol.8. No.4. P.532-538.

Martin J.W. 2003. Oplophorid shrimp (Decapoda, Caridea) from an Arctic hydrothermal vent // Crustaceana. Vol.76. No.7. P.871-878

Martin J.W., Davis G.E. 2001. An updated classification of the recent Crustacea // Nat. Hist. Mus. Scient. Ser. No.39. 123 p.

Mistakidis M.N. 1957. The biology of Pandalus montagui // Fishery investigations. Ser.2. Vol.21. No.4. P.8-26.

Nigmatullin Ch.M. 2000. [Oocyte resorption in cephalopods: history of investigations, preliminary typification and hypothesis on its role in regulation of level of actual fecundity] // Alimov A.F., Sirenko B.I., Egorova E.N. (eds.). Marine mollusks: taxonomy, ecology and phylogeny. St. Petersburg: Zoologicheskiy Institut RAN. P.65-67 [in Russian].

Oh C.-W., Ma C.-W., Hartnoll R.G. 2003. Reproduction and population dynamics of the temperate freshwater shrimp, Neocaridina denticulata (De Haan, 1844) in a Korean Stream // Crustaceana. Vol.76. No.8. P.993-1015.

Omori M. 1974. The biology of pelagic shrimps in the ocean // Advances in Marine Biology. Vol.12. P.233-324.

Ramirez-Llodra E., Segonzac M. 2006. Reproductive biology of Alvinocaris muricola (Decapoda: Caridea: Alvinocarididae) from cold seeps in the Congo Basin // J. Mar. Biol. Ass. U.K. Vol.86. P.1347-1356.

Relini L.O., Semeria M. 1983. Oogenesis and fecundity in bathial penaeid prawns, Aristaeus antennatus and Aristaeomorpha foliacea // Rapp. Comm. Int. Mer. Médit. Vol.28. No.3. P.281-284.

Schultze K. 1993. Experimentelle Untersuchungen zur Larvalentwicklung von Pandalus montagui (Leach, 1814) (Crustacea, Decapoda, Natantia) unter besonderer Berücksichtigung des Gonadensystems. PhD thesis. Diss., Univ. Hannover, Fachbereich Biologie, Germany. P.1-312.

Sudnik S.A. 2007. [Oogenesis of shrimp Glyphus marsupialis Filhol 1884 (Decapoda, Pasiphaeidae)] // Sokolov V.I. (eds) Morskie promyslovye bespozvonochnye i vodorosli (biologiya i promysel). VNIRO Proceedings. Vol.147. P.237-253 [in Russian]

Sudnik S.A. 2008. [Ecological aspects of srimp reproductive strategies]. PhD. Kaliningrad: KGTU. 313 p. [In Russian].

Sudnik S.A. 2015. [Ovaries maturation in deep-water pelagic shrimp Systellaspis debilis (A. Milne Edwards, 1881) (Crustacea: Decapoda: Caridea)] // Sovremennye problemy ispolzovaniya potentsiala morskikh akvatoriy i pribrezhnykh zon: materialy XI mezhdunarod. nauch. konf. Moscow: MU im. S.Yu.Vitte. Ch.1. P.242-257 [in Russian].

Sudnik S.A., Falkenhaug T. 2014. The method of biological analysis for caridean shrimps (Decapoda: Natantia: Caridea) with emphasis on pelagic shrimps. The science and society in the conditions of globalization: the materials of H34 International scientific and practical conference (Ufa, 21-22 April, 2014). Ufa: RIO ICIPT. P.7-11.

Tan-Fermin J.D. 1991. Effects of unilateral eyestalk ablation on ovarian histology and oocyte size frequency of wild and pondreared Penaeus monodon (Fabricius) broodstock // Aquaculture. Vol.93. P.77-86. 
Tchesunov A.V. 1984. [Materials to knowledge of genus Parapasiphaea (Crustacea, Decapoda)] // Zoologicheskiy zhurnal. T.63. No.8. P.1164-1174 [in Russian].

Ville J.-P. 1972. Cycle ovarien saisonnier chez Macrobrachium vollenhovenii (Herklots 1851) Decapoda, Palaemonidae // Annales de l'Université d'Abidjan. Série E (Ecologie). Vol.5. No.1. P.561-576.

Vinogradov M.E. 1968. [Vertical distribution of the oceanic zooplankton]. Moscow: Nauka. 320 p. [In Russian].
Wenneck de L.T., Falkenhaug T., Bergstad O.A. 2008. Strategies, methods, and technologies adopted on the R.V. G.O. Sars MAR-ECO expedition to the Mid-Atlantic Ridge in 2004 // Deep-Sea Research II. Vol.55. P.29-44.

Responsible editor V.A. Spiridonov 